\title{
A Robust Application of the Arbitrage Pricing Theory: Evidence from Nigeria
}

\author{
Oyetayo, Oluwatosin J., ${ }^{1}$ Adeyeye, Patrick Olufemi ${ }^{*}$ \\ ${ }^{1}$ Federal University of Agriculture Abeokuta, Nigeria \\ 2University of Kwazulu-Natal, Durban, South Africa \\ tosin_julie@yahoo.com, adeyeyepo@gmail.com
}

\begin{abstract}
Arbitrage pricing theory (APT) is a testable theory based on the idea that in competitive financial markets arbitrage will ensure that riskless assets provide the same expected return. We sought to confirm the relevance of the arbitrage pricing theory in Nigeria. Guided by a good understanding of macroeconomic variables and stock price movements as found in the extant literature on arbitrage pricing theory (APT), we specified our APT equation for estimation. Having satisfied the integration and co-integration issues, we employ the error-correction (ECM) and the fully modified ordinary least squares (FMOLS) methods for the short-run and long-run regressions. Our short-run results seem to agree with existing theories on APT thus confirming that APT is relevant in Nigeria. However, the long-run relationship of stock returns and RGDP was found to be contentious. Even though our result runs contrary to predictions on the relationship between the two, we found peculiar events and circumstances within the Nigerian macroeconomic context that provides logical reasons for the deviation.
\end{abstract}

Keywords: Equilibrium models, arbitrage pricing theory, capital asset pricing theory, macroeconomic variables

\section{Introduction}

In the contemporary finance literature, the application and testing of equilibrium models has become very popular. The reason is simple; many financial researchers have discovered the usefulness of such theoretical models for determining the sensitivity of equity stocks to systematic risks. Such theoretical models can also be useful in the calculation of time-weighted cost of capital. Talking about equilibrium models in finance, two of them readily come to mind: capital asset pricing model (CAPM) and arbitrage pricing model (APT). Both have their root in efficient market hypothesis (EMH), and constitute part of the modern portfolio theory. Fama (1965) describes EMH as a condition for measuring how well market information reflects in security prices per time. The essence is to ensure that security prices are neither over-priced nor under-priced in their valuation. At the initial stage, CAPM provided a good theoretical background for testing market efficiency. However, the assumptions underlying the model were later proven too simple and unrealistic to accurately describe what happens in the real world (Rosenberg, 1981; Schulmerich, Leporcher, \& Eu, 2015). Under the CAPM, a one-factor model is built from which stock returns are predicted. In this case, the only variable whose slope (i.e. beta) explains the changes in stock returns is the market portfolio return for all assets. Overtime, the subjection of this theoretical background to empirical testing has resulted in several conflicting results (Chen \& Fang, 2009).

Arriving at a true measure of value for the market portfolio of asset can be quite challenging (Davis, Fama \& French, 2000). The limitations in the application of CAPM to the real world situations has paved way for some other equilibrium models like the APT to become relevant in empirical applications. The APT developed by Ross (1976) introduced several factors as sources of systematic risks to stock returns. This is against the single variable with the single beta in the case of CAPM. APT houses more variables with a beta attached to each one of them. Usually, these variables are macroeconomic related which makes the model fit to explain to a large extent, the weight and dimension of systematic risks affecting stock returns. Another major hedge recorded by the APT over CAPM is that it relates stock returns and the macroeconomic factors in a linear fashion. This makes it possible to carry out a time series analysis on both the historical and future relationship that exists between stock returns and the multi-factors. Lastly, because APT allows the selection of multi-factors, which are macroeconomic related, it makes the practical application more interesting (Fama \& French, 1992, 1996, 1997; Campbell, Lo \& MacKinlay, 1997; Cochrane 2001). The APT was built on the assertion that there are both limited and non-correlated common factors that affect equity price. Among these factors is a particular one, which is totally independent from others (Campbell, Lo \& MacKinlay, 1997). On this assertion, this paper is premised. While the testing of APT for developed economies is quite large, scanty works exists for the application of this interesting financial theory in many of the emerging economies 
especially in Africa. We therefore ask: is the arbitrage pricing theory only applicable to the developed economies? Can the factors identified in the literature exhibit significant effect on stock returns in a country like Nigeria? The rest of this paper is divided into four parts, which include; review of literature, methodology, results and conclusion.

\section{Literature Review}

No doubt when it comes to asset pricing and equity valuation, CAPM and APT models have been quite influential. Even though the assumptions underlying APT have been found to be less restrictive than those of CAPM, researchers still find it difficult to discard CAPM in its entirety. The emphasis in APT is providing an explanatory model as against the statistical model presented in CAPM (MacKinlay, 1995; Campbell, Lo \& Mackinlay, 1997). Under the APT, investors are assumed to hold in their portfolios, securities with varied risks and returns affected differently by different factors. This is unlike the CAPM where the diverse risks and returns associated with securities in a portfolio are enveloped under the market risk and return. Another comparison of the APT and CAPM reveals that the APT presents a model that somewhat looks like a "supplyside" model, while the CAPM presents a "demand side" model (Goetzmann \& Ibbotson, 2006; Jewczyn, 2014). The logic behind this is that in APT, beta coefficients of the identified factors explain the level of sensitivity of the underlying asset to these factors. The expected returns on the asset is as initiated or brought about by shocks to the identified factors (Brennan, Wang \& Xiu, 2004). In the case of CAPM, the change in asset return brought about by its sensitivity to market returns is assumed to be initiated by the investors' desire to maximize his utility from the resulting market equilibrium. As consumers of assets, investors seeking to make more returns from assets held will always bring the market back to equilibrium (Brennan et al., 2004).

The goal of APT is that all risky assets prices within an economy exhibit no arbitrage condition. A condition of no arbitrage occurs when no individual investor with a portfolio that is well diversified is able to make excess return just by changing the weights of assets under his portfolio. This is with the assumption that both the systematic and unsystematic factors remain unchanged. Giving a vivid description of the kind of linear function specified by APT, Ross (1976), Chen, Roll and Ross (1986), provided a baseline equation to uphold their position. This is supported by Conor (1995), DeFusco, Mcleasey, Pinto \& Runkle (2004) and Chen \& Fang (2009). They explained that the risk factors considered in an APT model usually arises from changes relating to some fundamental economic and financial variables. These variables include interest rates, expected inflation, market index, real business activity and market ratings. From the description above, a linear equation of the following form is generated as follows:

$E\left(R_{i}\right)=\theta_{i}+\psi_{i 1} E_{1}+\psi_{i 2} E_{2}+\ldots \ldots \psi_{i k} E_{k}+\varepsilon_{i}$

Where $E\left(R_{i}\right), i=1,2,3 \ldots n$ is the expected return of the stock $i ; E_{j}=1,2,3 \ldots . k$ are the selected economic factors. $\psi_{i j}$ is the sensitivity of security $i$ to the economic factors $E_{i j} \cdot \theta_{i j}$ represents the uncontrolled factors that influence asset risk. $\varepsilon_{i}$ is the error term.

The model above is popularly called the $k$-factor model upon which several other APT models have been built overtime (Chen \& Fang, 2009).Two main methods have been found in the financial and economic literature to empirically test the APT(Brennan et al., 2004; Chen \& Fang, 2009). First, a simultaneous estimation of asset sensitivities and unknown factors can be carried out through what is called explanatory factor analysis on stock returns. Under this approach, there is no prediction of the exact number of content or the number of relevant factors. Second, there could be a specification of factors that explain asset values prior to the analysis. Such factors could be macroeconomic variables that affect future cash flow of organisations' operations or future cost of capital. Based on empirical evidences, a comparison of the two reveals that the second approach is more acceptable (Chen \& Fang, 2009). It is believed that it provides a more attractive, dynamic and flexible option for factor composition in APT research. 
For the purpose of factor identification, again the financial literature is replete with studies that have identified relevant macroeconomic variables that influence stock returns. A thin line of difference can actually be drawn when carrying out APT analysis for a sample and the entire population. A sample in this case will be a collection of securities or assets portfolio selected from the stock market. Whereas, the entire population of assets will be the market indices of all securities traded in the stock market. Where the entire population of asset in the stock market is being considered for analysis, then the relevant macroeconomic variables that affect aggregate economic activities are to be considered. Such was what Chen, Roll and Ross (1986); Davis, Fama and French (2000); Schulmerich (2012a), identified as (i) shocks in inflation (ii) shocks in gross domestic product (GDP) (iii) shocks in investor perception of market conditions (iv) shocks in the movement of the yield curve. In order to capture the market indices, sometimes, the factor analysis is employed. Alternatively, other indices that are considered as direct indices may be adopted. They include long and short-term interest rates differentials, a diversified stock or composite index, oil prices, foreign exchange rates, etc.

Empirical investigations of APT have been carried out in various degrees and intensities across the developed and emerging economies. Quite remarkable that most of these studies come from the United States (Ross, 1976; Roll \& Ross, 1980; Conor 1995; Chen \& Fang, 2009). A few of them also come from Europe, especially the Scandinavian countries. While in the category of emerging economies, studies from Asian countries takes the lead with very few coming from Africa. Ross (1976) pioneered the practical application of the arbitragepricing model using daily data for individual equities quoted on the New York Stock Exchange (NYSE) for the period 1962-72. Their result actually gave credence to the fact that the APT model better explains variations in equity return than the CAPM. Among other things, their result shows that about four macroeconomic factors, which are themselves priced, demonstrate a high level of influence on stock returns over the period of study. Chen (1983) further established the superiority of the APT model using data for the period 1963-78. By comparing the empirical outcome of the APT with that of the CAPM, his findings seem to put a final seal on the supremacy of the APT over CAPM.

Apart from the relevance of the explanatory power of the factor analysis in APT, another issue that authors have found interesting when testing the theory is the number of securities that make up a sample or population. There is the tendency that the more the number of securities under investigation, the more the number of explanatory factors that will be found relevant (Harding, 2007).The implication of this is that stock exchanges that warehouse more equities will naturally have more macroeconomic factors explaining stock returns and vice-versa. By extension, most of the developed economies that have well established stock exchanges with a good number of equity listings will have a more robust APT model than the emerging or developing ones. Unfortunately, not too many research works have been carried out on the relevance of the APT in developing economies. This has limited the desire to compare the result from developed and developing economies. Another challenge in relation to samples and population in APT studies is that finite samples risk the inability to distinguish all the latent factors, which may result in a biased result (Harding, 2007).

Besides APT studies carried out in the US where the theory emanated from, we found several other studies from other developed economies mostly European that have interesting results. Diacogiannis (1986), Abeysekra and Mahajan (1988), Ostermark (1989), Yli-olli, Virtanen and Martikainen (1990), Reilly and Brown (2003), Cagnetti (2009), are all examples of APT studies carried out in Europe. Yli-olli et al. (1990) used monthly data samples from two neighbouring countries (Finland and Sweden) for the period 19771986. Employing the principal component analysis cum transformation analysis, and subsequently, the crosssectional regressions, their result shows that three priced factors determined stock returns in the two countries for frequently traded stocks while there are two priced factors for infrequently traded stocks in the two countries. In addition, it was mentioned in their work that Martikainen, Yli-Olli and Gunasekaran (1991) carried out another study on the stock market in Finland using monthly data. Their focus was to determine which of the two approaches in APT produces better result on explanatory factors for two separate periods of 1977-81 and 1982-86. The principal component analysis was used for 1977-81. The factor loadings derived were subjected to OLS regression. For the second approach, covering the period 1982-86, they specified eleven macroeconomic factors as explanatory variables to be tested in the APT model. When compared, the result from the first approach reveals that only one-priced factor was significant for the period covered. 
Whereas, the result of the second approach shows that all the explanatory variables have significant effect on stock returns. In addition, the relevance of foreign economic activity (i.e. fluctuations in real exchange rates) and unexpected inflation to stock returns has also been established in the literature. As reported in Loflund (1992), apart from macroeconomic factors such as changes in short-term interest rates, inflation and real GDP, other factors can also be included in the APT research like changes in real exchange rates, net export and world oil price.

Empirical evidences on equilibrium models for capital markets in developing economies are quite few. Not only are they few, but that their concentration is majorly on stock exchanges in Asia. Khilji (1993), later supported by Hussain and Uppal (1998), concluded that the stock returns features on the Karachi Stock Exchange cannot be adequately modelled by a normal distribution. Khilji (1994) went further to establish that the series of stock returns over time might not be linearly dependent on explanatory factors. Some other authors like Attuallah (2001) who used the iterative non-linear seemingly unrelated regression on the Karachi Stock Exchange monthly data on returns have supported this non-linear relationship. Most of the factors that showed significant effects were external in nature; i.e. exchange rate, trade balance and world oil price. Hence, we conclude that in the long run, foreign related macroeconomic factors may have non-linear relationship with returns (Kutty, 2010; Zubair, 2013; Masood \& Sarwar, 2015) while other macroeconomic factors, which are internal, have a linear relationship with returns. There are many more empirical evidences in support of this view, some of which are found in Singh, Mehta \& Varsha, 2011and Kuwonu \& OwasuNantwi, 2011. Singh, Mehta and Versha (2011) did a study on the Taiwan Stock Exchange. They focused on the link between index returns and some key macroeconomic variables, which are GDP, inflation rate, employment rate and money supply. Their results show that both GDP and exchange rate positively affect returns of all portfolios, while exchange rate, inflation rate and money supply negatively affect returns for portfolios of both big and medium-sized firms.

While the application of the arbitrage pricing equilibrium model may not be common in the African finance literature, empirical evidences on stock returns and macroeconomic factors abound in good number. Chakaza (2008) investigated the relationship between systematic factors and stock prices in Zimbabwe. He used systematic factors that are financial in nature with the expectation that these factors cause a unidirectional effect on stock prices. He concluded that those systematic factors have significant effects on stock returns. Still on Zimbabwe, Jecheche (2012) pushed the argument further by establishing that under different methods, different results could be achieved. Using the causality test, he found a unidirectional causality from consumer price index to stock returns. Interestingly, while causality test shows that there is no relationship between stock prices and exchange rate, the impulse response analysis shows that exchange rate has significant effects on stock returns. Kuwomu and Owasu-Nantwi (2011) presented the Ghanaian evidence on stock returns and macroeconomic variables. Using the full information maximum likelihood estimation, they established that exchange rate and Treasury bill rate had significant effects on stock returns within the study period.

In Nigeria, financial and economic researchers have explored, in different forms, the relationship between stock market returns and economic growth usually proxied with gross domestic product. Most of these studies have been directed at evaluating the policy efficacy and effectiveness of macroeconomic factors. For instance, in order to look at the relationship between stock market development and economic growth, Ogun and Iyoha (2005) used the real gross domestic product with lagged values of market capitalization for the stock market within the period 1970-2003. They found positive relationship between stock market and economic growth. Others have focused on the direction of causality between stock market return and economic growth. Nyong (1996) discovered that stock market development significantly correlated with long-run economic growth. He went further to establish that there exists a bi-directional causality between capital market development and economic growth. Again, Ogboi and Oladipo (2012) sought to examine the nexus between stock market and economic growth. They concluded that there exist a uni-directional causality between stock market and economic growth with economic growth causing stock market. However, they observe that within the period of their study, stock market has a long-run positive effect on economic growth. Also, Zubair (2013) used granger causality test to shed more light on the nexus between stock returns and monetary indicators (i.e.M2 and exchange rate). He established the absence of direct linkage between all-share index (ASI) and exchange rate thus giving credence to Khilji (1994) and Attuallah (2001). 
With particular reference to APT studies in Nigeria, we found quite a few that caught our attention. Isemila and Erah (2012) investigated the application of APT in Nigeria. We found the number and nature of macroeconomic variables (oil prices, money supply, GDP and exchange rate) adopted not adequate for an extensive APT research. The exclusion of inflation rate and interest rate in their model is a major concern for us. The multi-collinearity test carried out by the authors is quite impressive, but they failed to support their result with theoretical backgrounds on the interaction of the affected variables. The high collinearity value recorded for GDP may be because inflation was not accounted for in the computation of GDP data. Accounting for inflation in GDP data would have resulted in the use of real GDP, which is a better variable in this case. In our own opinion, the inclusion of oil price and exchange rates, which are both subsets of foreign activity, may foretell multi-collinearity (Harri, Nalley \& Hudson, 2009; Aziz 2009; Ferraro, Rogoff \& Rossi, 2015).Similarly, Izedonmi and Abdullahi (2011) who adopted two macro-economic variables (inflation rate and exchange rate) left out the 'juicy ingredients' in their APT study. In addition, the use of market capitalisation as a proxy for returns on stock market portfolio of assets is not consistent with literature (Black 1972; Reilly and Brown, 2003). The combination of market capitalization, exchange rate and inflation rate in a model without the semi-log system may be a catalyst for a spurious result. Nevertheless, we found relevance in the results of some of the earlier APT studies in Nigeria.

\section{Methodology}

Data consists of quarterly closing points of the macroeconomic variables and all-share index covering the period 1985Q1- 2014Q4. These are collected from the Central Bank Statistical Bulletin. Five explanatory macroeconomic variables that are prominent in the literature are identified and adopted for analysis in this study. They is defined in line with their a priori expectations as follows:

Inflation rate (CPI): as observed by some authors from different countries, stock returns could have a negative relationship with changes in both expected and unexpected inflation (Al-Qenae, Li and Wearing, 2002; Nishat and Shaheen, 2004). It has been established that a rise in inflation can cause a rise in interest rate, which in turn, can cause a fall in stock prices (Osinubi and Amaghionyediowe, 2003).

Interest rate: it acts as the transmission mechanism through which the effect of inflation is channelled to the real sector. The discount factor used in stock valuation is directly dependent on interest rate. Therefore, an increase in interest rate can trigger an increase in the discount factor, which can subsequently bring down stock value (Uanguta and Ikhide, 2002; Ogunkola and Abubakar, 2008).

Domestic credit: this is a variant of money supply and it is expected to have the same effect as money supply. Money supply typically has been a leading indicator in macroeconomic issues. Financial economics proves that money supply and demand have effect on equity prices (Barro,1990; Martikainen et al. 1991; Apte, 2001). Like interest rate, money supply has been identified as a transmission mechanism through which the effect of inflation is channelled to stock returns. In addition, it determines the future cash flow through the discount factor, which in turn determines the stock value (Binswanger, 2000).

Exchange rate: this is considered another relevant macroeconomic factor following Singh, Mehta and Versha, 2011; Kuwormu \& Onwusu-Nantwi, 2011, who found significant linkage between exchange rates and stock prices. Dornbusch and Fisher (1980) developed an integration model for determination of exchange rate and concluded that rising stock market prices trigger domestic currency appreciation through direct and indirect channels. While exchange rate depreciation in the long run may lead to increase in stock market prices in some countries, exchange rate depreciation in the short run may bring about reduction in stock market returns in some situations. This position is supported by (Aydemir and Demirhan, 2009; Zubair 2013).

Gross domestic product (GDP): the growth rate of GDP is noted to be the most important performance indicator of the economy (Fama, 1981). Consequently, GDP is expected to have great influence on other sectors of the economy. The relationship between GDP and stock market returns in many cases has turned out to be positive (Fama,1981,1990; Dermirgue-Kunt and Levine,1996; Haris 1997; Chandra 2004; Obamiro, 
2005). The implication of this is that as long as the economy is recording increases in domestic output, it is a signal that industries and organisations operating within the economy are also doing well.

\section{Estimation and Results}

Following the original APT model specified by Ross (1976), and the subsequent identification of relevant factors, we estimated the following equation:

$$
A S I_{t}=\beta_{0}+\beta_{1} \operatorname{In} R G D P_{t}+\beta_{2} T B_{t}+\beta_{3} C P I_{t}+\beta_{4} \operatorname{InDC}_{t}+\beta_{5} E X_{t}+\mu_{t} \cdots
$$

Where $A S I=$ all-share index; $R G D P=$ real GDP; $T B=$ treasury bill rate; $D C=$ domestic credit and $E X=$ exchange rate and $\mu$ is the error term. $\beta_{0}, \beta_{1} \ldots \beta_{5}$ are the parameters to be estimated.

A test of unit root properties of the variables using the Augmented Dickey Fuller (ADF) and Phillips Peron shows that all are significant at first difference except logRGDP, which was significant at levels. As presented below, the co-integration result from both the Trace and Maximum-Eigen tests indicates the presence of three and one co-integration relationship (s) in the model respectively.

Table 1: Co-integration Analysis

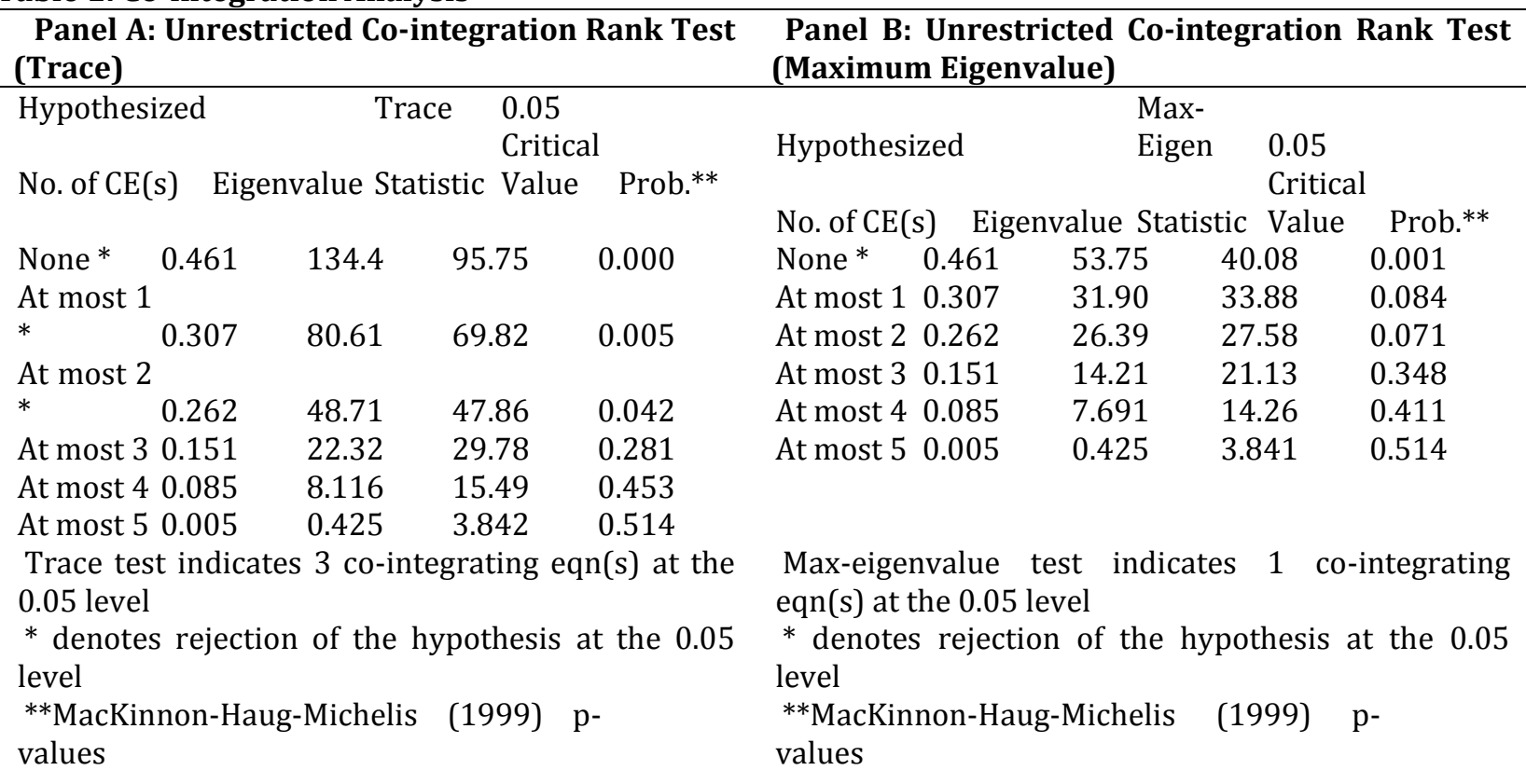

Table 1 above shows the co-integration analysis. Panel A shows the co-integration result using the Trace test while Panel B shows the maximum-Eigenvalue result. The first column on both sides reports the number of possible co-integration relationships. Both the Trace and Max-Eigen tests considers critical values for cointegration relationships at ** which indicates 5percent level of significance. From the foregoing, we go ahead to test for both the short-run and long-run effects using the error-correction and fully modified least square methods, respectively. We present the results in Tables $2 \& 3$ as follows:

Table 2 below shows the short-run regression result derived from the error-correction analysis. The errorcorrection indicator and the lagged variables are contained in Column 1, regression co-efficient values in column 2, standard error of estimates in column 3 and column 4, the t-statistics taken at probability levels of $*^{*}=10 \%$; ${ }^{* *}=5 \%$; $* *=1 \%$, respectively. The error-correction indicator of less than $1 \%$ at $5 \%$ level of significance shows that just about $1 \%$ of previous period's disequilibrium in stock returns occasioned by the factors in view is corrected in the long run. Below the variables is vital statistical information about the estimated equation. Akaike information .criterion and Schwartz criterion show negative signs as expected 
indicating the adequacy of our lag length. Durbin Watson value of 1.8 indicates our model is devoid of serial autocorrelation.

Table 2: Short-run Regression Result (Error-correction Method) Dependent Variable :

D(ASI)

Least Squares Method

\begin{tabular}{lcccc}
\hline Variable & Co-efficient & Std. Error & t-Statistic & Prob. \\
\hline C & & & & \\
ECM(-1) & $0.053^{* * *}$ & 0.012 & 4.308 & 0.000 \\
D(CPI(-1)) & $-0.001^{* *}$ & 0.000 & -2.097 & 0.039 \\
D(EX(-2)) & $-0.003^{* * *}$ & 0.001 & -3.959 & 0.000 \\
D(TB) & $-0.005^{* * *}$ & 0.001 & -3.229 & 0.002 \\
D(ASI(-1)) & $-0.007^{* * *}$ & 0.001 & -4.428 & 0.000 \\
R-squared & $0.257^{* *}$ & 0.100 & 2.558 & 0.012 \\
Adj.R- squared & 0.363 & & & \\
F-statistic & 0.329 & & & \\
Prob(F-statistic) & 10.60 & & & \\
Akaike Info. criterion & 0.000 & & & \\
Schwartz criterion & -1.597 & & & \\
Durbin-Watson statistic & -1.440 & & & \\
\hline
\end{tabular}

Table 3: Long-run Regression Result (Fully Modified Least Squares)

Dependent Variable :

$\mathrm{D}(\mathrm{ASI})$

Least Squares Method

\begin{tabular}{lcccc}
\hline Variable & Co-efficient & Std. Error & t-Statistic & Prob. \\
\hline C & $0.078^{* * *}$ & 0.013 & 6.018 & 0.000 \\
D(CPI) & -0.001 & 0.001 & -0.677 & 0.500 \\
DLOG(DC) & $-0.001^{* *}$ & 0.000 & -2.234 & 0.028 \\
D(EX) & -0.002 & 0.002 & -1.251 & 0.214 \\
DLOG(RGDP) & -0.010 & 0.034 & -0.294 & 0.769 \\
D(TB) & $-0.007^{* * *}$ & 0.002 & -3.572 & 0.001 \\
& & & & \\
R-squared & 0.194 & & & \\
Adj.R- squared & 0.149 & & & \\
S.E of Regression & 0.116 & & & \\
Durbin-Watson statistic 1.509 & & & \\
\hline
\end{tabular}

We note in Table 2 that all the explanatory variables have significant negative effects on stock market returns in the short run except for the lag of ASI. D(ASI(-1)) has positive effects which is significant. The level of their significance gives credence to the strength of their effects in the short run. The negative relationship that inflation, interest rate and exchange rate respectively have with stock prices also agrees with the positions of earlier studies like Stulz (1986); Kaul (1987); Li and Wearing (2002); Ibrahim and Aziz (2003); Osinubi and Amaghionyediowe (2003); Isemilla and Erah (2012); Ogunkola and Abubakar (2008). In order to estimate the long-run relationship, we use the fully modified least squares (FMOLS): Phillips and Hansen (1990), for our I(1) and I(0) regressors . FMOLS is reputed to give optimal estimates of co-integrating regressors. Under this method, possible serial correlation effects and endogeneity in the regressors are properly accounted for. Amongst other things, FMOLS has also been found relevant in models with I(1) and I(0) regressors (Phillips 1995). Table 3 above contains the estimates of the long-run regression using the fully modified least squares method. Columns 1 contain the parsimonious variables, Column 2, the regression coefficients of the variables, Column 3, standard error of estimates. Column 4 and 5 contains the t-Statistics and the associated probability 
values. ${ }^{* * *}, * *, *$ indicate significance at 1,5 and 10 percent respectively. As seen in the table, our DurbinWatson of 1.5 dismisses the possibility of serial-autocorrelation.

The long-run regression in Table 3shows that all the factors still have a negative effect on stock returns at varying levels of significance. DW is still within the acceptable range of 1.5-2.0. Following Martikainen et al. (1991), domestic credit which is a variant of money supply is expected to have a positive relationship with stock returns, but our result shows a negative co-efficient of -0.00000009 .84 for DC at $5 \%$ level of significance. Treasury bill rate representing short-term interest rate records a negative co-efficient of 0.006538 significant at 1\%, which confirms the prediction of Martikainen et al (1991), Barro (1990), and Fama (1990). Other variables observed are not significant. Even though it is predicted that exchange rate depreciation and GDP should have positive relationship with stock prices in the long run (Apte, 2001; Dornbush and Fisher 1980; Chandra 1994), our result shows negative coefficients for these variables although they are not significant. CPI is also predicted to have negative relationship with stock price (Stulz, 1986: Kaul 1987). However, our result shows a negative but insignificant coefficient of -0.000773.Lastly, in line with the position of Khilji (1994), we found that over time, the strength of the variations in stock returns explained by the explanatory factors decreased significantly from $36 \%$ to $19 \%$.

\section{Conclusion}

Our aim was to find out if the APT model was relevant in Nigeria. The period selected (1985-2014) was such that we believe encompasses diversities in the financial and trading activities of the country. Our source of data; (CBN bulletin) we believe is very reliable so that we do not have concerns over some of the deviations observed in our result. As much as possible, we managed the analysis using the relevant techniques. We draw our conclusion from this work that in the short run three priced factors: inflation, exchange rate and Treasury bill have significant negative effects on stock returns as expected. In the long run, domestic credit and Treasury bill rate are the two priced factors that have influenced stock returns in Nigeria for the period under study. Some of the factors, which were predicted to have positive effects but returned negative, may be due to the peculiar nature of the investment and consumption pattern of the country. Nigeria embarked on full devaluation of naira since 1986 and it is expected that in line with theory, this would boost local investments and have a spillover effect on stock market. However, being a consuming nation, Nigeria's importation drive has continued leaving very few resources to be invested in the real sector which the stock market represents.

The negative coefficient of GDP as against the predicted positive coefficient of GDP may be due to the existence of a bi-directional causality between GDP and Stock Market development (Nyong 1996). Stock market index return, a key indicator of development in the stock market, reveals the growth rate in the value of the listed firms for all the industries operating in the economy. GDP measures the value of goods and services produced within the economy. It is expected that as more goods and services are produced in the economy, income will increase, investment fund will also increase some of which will find their way to the stock market. Increase in investment in the stock market will bring more capital to the listed companies and ultimately increase their production activities. In turn, increase in the production of listed companies will add to increase in production for the economy at large. The Nigerian economy for a long time has been monocultural depending mainly on crude oil extraction and production of petroleum and allied products. Therefore, crude oil production has accounted for about $80 \%$ of its GDP which is still prevalent. For about half of the period that this study covers, most of the factors that have led to the growth in GDP cannot be traced to the stock market including Increases in oil price, establishment of telecommunication services most of which are not quoted on the stock exchange coupled with the stock market crash which started in the last quarter of 2007 and investments in the stock market which have been transferred to some other areas of direct investment in the economy. The stock market is yet to recover from this downslide position as the GDP has continued to rise.

In addition, we could not exhaust the information on the relationship of stock returns with exchange rate. Exchange rates, like some other externally determined variables, have been proven to have a non-linear relationship with stock returns in the long run. The seemingly unrelated regression analysis would be a better method for this. We found it cumbersome juggling between variables that have a linear relationship and one with a non-linear relationship using different methods of analysis at the same time. More so that our 
focus for this research is on the internally determined priced factors. Perhaps in the future, we may carry out another analysis on the application of APT to Nigeria, bringing together with exchange rate other externally determined priced variables. In this case, the seemingly unrelated regression analysis will be employed. We may also include other factors whose long-run relationship with stock returns have been controversial to see if they will display useful characteristics under this method.

At this point, it is important to state that in all, the APT model formed in this study and the variables used looks like a comparison of the capital market and money market. While the stock returns represent the capital market, the explanatory variables are all derived from money market activities. The negative or inverse relationship between inflation, exchange rate, Treasury bill and stock return in the short run can be used to predict the impact of monetary policy on the stock market. Of all the priced factors, Treasury bill is found to be relevant both in the short run and in the long run. Like all other factors with negative effects, when Treasury bill is booming, the stock market is bleeding. As against government borrowing through Treasury bill, government can resort to external borrowing without putting pressure on the available scarce investment funds thereby short-changing the stock market. The GDP as well as the stock market indices are regarded as strong indicators of growth in any economy. It is high time Nigeria placed less emphasis on GDP and more emphasis on the stock market indices as true measures of economic growth. Discrepancies between stock market indices and GDP values should be an indication that there is a mismatch in investment, production and output. Stock market points to the real sector investment while GDP indicates real sector output. It therefore behoves on policy makers to understand that output accounted for in GDP is not internally driven. Government will therefore be justified imposing all measures aimed at boosting local production.

\section{References}

Abeysekera, S. P. \& Mahajan, A. (1988). A Test of the APT using UK Stocks, Journal of Business Finance and Accounting, 14, 377-391

Al-Qenae, R., Li, C. \& Wearing, B. (2002). The information content of Earnings on Stock prices: The Kuwait Stock Exchange. Multinational Finance Journal, 6(3), July

Apte, P. (2001). The Interrelationship between Stock Markets and the Foreign Exchange Market. Prajnan, 30, 17-29

Attuallah, A. (2001). Macroeconomic Variables as Common Pervasive Risk Factors and Empirical Content of the Arbitrage Pricing Theory in Pakistan. Lahore Journal of Economics, 6(1), 55-77.

Aziz, M. I. A. \& Bakar, A. (2009, August). Oil Price \& Exchange Rate: A Comparative Study between Net Oil Exporting and Net Oil Importing Countries. In ESDS International Annual Conference, London.

Aydemir, 0. \& Demirhan, E. (2009).The Relationship between Stock Returns and Exchange Rates: Evidence from Turkey. International Research Journal of Finance and Economics, 23, 207-215.

Barro, R. (1990). The Stock Market and Investment. Review of Financial Studies, 3, 115-131.

Binswanger, M. (2000). Stock Returns and Real Activity: Is there still a Connection? Applied Financial Economics, 10, 379-387

Black, N. (1972). The Effects of Macroeconomic Factors on Stock Returns: Istanbul Stock Market. Studies in Economics and Finance, 26(1), 36-45.

Brennan, M. S., Wang, A. W. \& Xiu, Y. (2004). Estimation and Test of a Sample Model of Inter-temporal Capital Asset Pricing. Journal of Finance, 59, 1743-1775. August

Cagnetti, A. (2009). Capital Asset Pricing Model and Arbitrage Pricing Theory in the Italian Stock Market: An Empirical Study, available at http//:www.era.lib.ed.ac.uk/bitstream/handle/1842/1821, retrieved on $12 / 12 / 2015$

Campbell, J. Y., Lo, A. W. \& MacKinlay, C. A. (1997). The Econometrics of Financial Markets (revised edition), Princeton - New Jersey: Princeton University Press

Chakaza, R. (2008). The Fiscal and Monetary Linkage between Stock Returns and Inflation in Zimbabwe. The Journal of Finance, 38(1), 1-33.

Chen, A. \& Fang, S. (2009). Uniform Testing and Portfolio Strategies for Single and Multi-Factor Asset Pricing Models in the Pacific Basin Markets. Applied Economics, 41(15), 1951-1963

Chen, N. F. (1983). Some Empirical Tests of the Theory of Arbitrage Pricing. Journal of Finance, 38(5), 13931414. December 
Chen, N. F., Roll, R. \& Ross, S. A. (1986). Economic Forces and the Stock Market. Journal of Business, 59, 383403.

Cochrane, J. H. (2001). Asset pricing, Princeton-New Jersey: Princeton University Press

Conor, G. (1995). The Three Types of Factor Models: A Comparison of their Explanatory Power. Financial Analyst Journal, 15, 42-46

Davis, J. L., Fama, E. F. \& French, K. R. (2000). Characteristics, Covariances and Average Returns: 1929 to 1997. Journal of Finance, 55(1), 389-406

DeFusco, R. A., McLeavey, D. W., Pinto, J. E. \& Runkle, D. E. (2004). Quantitative Methods for Investment Analysis ( $2^{\text {nd }}$ edition), Charlottesville: CFA Institute

Demirguc-Kunt, A. \& Levine, R. (1996) Stock Markets, Corporate Finance and Economic Growth: An Overview. The World Bank Economic Review, 10(2), 223-239

Diacogiannis, G. P. (1986). Arbitrage Pricing Model: A Critical Examination of its empirical Applicability for the London Stock Exchange. Journal of Business Finance and Accounting, 12, 489-504

Dornbusch, R. \& Fisher, S. (1980). Exchange Rates and the Current Account. AER, 70(5), 960-971.

Fama, E. F. (1965). Random Walks in Stock Market Prices. Financial Analysts Journal, 5, 135-150

Fama, E. F. (1981). Stock Returns, Real Activity, Inflation, and Money. American Economic Review, 71, 545-65.

Fama, E. F. (1990). Stock Returns, Expected Returns, and Real Activity. Journal of Finance, 45, 1089-180.

Fama, E. \& French, K. (1992). The Cross-Section of Expected Stock Returns. Journal of Finance, 47, 427-465.

Fama, E. \& French, K. (1996). Multifactor Explanations of Asset Pricing Anomalies. Journal of Finance, 51, 5584.

Fama, E. \& French, K. (1997). Industry Costs of Equity. Journal of Financial Economics, 43, 153-93.

Ferraro, D., Rogoff, K. \& Rossi, B. (2015). Can oil prices forecast exchange rates? An empirical analysis of the relationship between commodity prices and exchange rates. Journal of International Money and Finance, 54, 116-141.

Goetzmann, W. N. \& Ibbotson, I. (2006). The Equity Risk Premium: Essays and Exploration, Oxford Yale: Oxford University Press

Harding, M. (2007) Explaining the Single factor bias of Arbitrage Pricing Models in Finite Samples. Economic letters, 99(1), 85-88

Harris, R. D. F. (1997). Stock Markets and Development: A Re-Assessment. Journal of European Economic Review, 41, 139-46

Harri, A., Nalley, L. \& Hudson, D. (2009). The Relationship between Oil, Exchange Rates and Commodity Prices. Journal of Agricultural and Applied Economics, 41(2), 501-510, August

Hussain, F. \& Uppal, J. (1998). Distribution of Stock Returns in an Emerging Market: The Pakistani Market. Pakistan Economic and Social Review, 36(1), 47-72.

Ibrahim, M. H. \& Aziz, H. (2003). Macroeconomic Variables and the Malaysian Equity Market. Journal of Economic Studies, 30, 6-27

Isemila, P. A. \& Erah, D. O. (2012). Share Prices and Macroeconomic Factors: A Test of the Arbitrage Pricing Theory in the Nigerian Stock Market. European Journal of Business and Management, 4(15), 66-76

Izedonmi, F. \& Abdullahi, B. (2011). The Effects of Macroeconomic Factors on the Nigerian Stock Returns: A Sectorial Approach. Global Journal of Management and Business Research, 11(7), 24-30

Jecheche, P. (2012). An Empirical Investigation of Arbitrage Pricing Theory: A Case of Zimbabwe. Research in Business and Economics Journal, 6(1).

Jewczyn, N. (2014). Theory and Portfolios: An Economic History of MPT and APT, International Journal of Economics \& Social Sciences, 3(2).

Kaul, G. (1987). Stock Returns and Inflation: The Role of the Monetary Sector. Journal of Financial Economics, $18,253-276$

Khilji, N. M. (1993). The Behaviour of Stock Return in an Emerging Market: A Case Study of Pakistan. Pakistan Development Review, 32(4), 593-604.

Khilji, N. M. (1994). Non-linear Dynamics and Chaos: Application to Financial Market in Pakistan. Pakistan Development Review, 3(4), 1417-1429.

Kutty, G. (2010). The Relationship between Exchange Rates and Stock Prices: The Case of Mexico. North American Journal of Finance and Banking Research, 4(4), 1-20

Kuwormu, J. K. A. \& Onwusu-Nantwi, V. (2011). Macroeconomic Variables and Stock Market Returns: Full Information Maximum Likelihood Estimation. Research Journal of Finance and Accounting, 2(4), 4963 
Loflund, I. (1992). Arbitrage Pricing Theory in a Small Open Economy: Empirical Evidence from the Swedish Stock Market. For skningsrapport, Svenska Handelshogskolan, Helsingborg

MacKinlay, A. C. (1995). Multi-factor Models do not explain Deviations from the CAPM. Journal of Financial Economics, 38, 3-28

Martikainen, T., Yli-Olli, P. \& Gunasekaran, A. (1991). Incremental Significance of Pre-specified Macroeconomic Factors in Testing the Arbitrage Pricing Theory: Empirical Evidence with Finnish Data. Applied Financial Economics, 1, 139-147

Masood, S. \& Sarwar, S. (2015). Relationship between Stock Prices and Exchange Rates: A Bivariate and Multivariate Analysis from Pakistan's Economy. International Affairs and Global Strategy, 32, 1-20

Nishat, M. \& Shaheen, R. (2004). Macroeconomic Factors and Pakistani Equity Market. The Pakistan Development Review, 43(4), 619-637

Nyong, M. O. (1996). Capital Market Development and Long-Run Economic Growth: Theory, Evidence and Policy Proposal for another Development Strategy, In J.E.U. Ndebbio \& U.Essia (Eds.), Nigeria and Development Strategy,129-155, Calabar: But-Bass Educational Book

Obamiro, J. K. (2005). Nigerian Economy: Growth and the Role of Stock Market. Journal of Economic and Financial Studies, 2(2)

Ogboi, C. \& Oladipo, S. O. (2012). Stock Market and Economic Growth: The Nigerian Experience. Research Journal of Finance and Accounting, 3(4), 103-110

Ogun, T. P. \& Iyoha, F. O. (2005). The Nigerian Stock Market and the Future Economic Activity: Does Deregulation of the Financial Market makes any Difference? Union Digest, 9(1\&2), 31-47

Ogunkola, E. \& Abubakar, T. (2008). Monetary Policy Transmission Mechanism in SierraLeone: A Vector Error Correction Approach, Ibadan: CEAR

Osinubi, T. S. \& Amaghionyediowe, L. A. (2003). Stock Market Development and Long-Run Growth in Nigeria. Journal of African Business, 4(3), 103-129

Ostermark, U. (1989). Arbitrage Pricing Models for two Scandinavian Stock Markets. Omega International Journal of Management Science, 20(4), 46-67

Phillips, P. C. B. (1995). Fully Modified Least Squares and Vector Autoregression, Econometrica, 63(5), 10231078, September

Phillips, P. \& Hansen, B. (1990). Statistical Inference in Instrumental Variables Regression with I (1) Processes, Review of Economic Studies, 57, 99-125

Reilly, F. K. \& Brown, K. C. (2003). Investment Analysis and Portfolio Management, Ohio, USA: Thomson South-Western

Roll, R. \& Ross, S. A. (1980). An empirical investigation of the Arbitrage Pricing Theory. Journal of Finance, 35, 1073-1103

Rosenberg, B. (1981). The Capital Asset Pricing model and the Market model. Journal of Portfolio Management, 7(2), 5-16. Winter

Ross, S. A. (1976). The Arbitrage Pricing Theory of Capital Asset Pricing. Journal of Economic Theory, 13, 341360

Schulmerich, M. (2012a). The Efficient Frontier on Modern Portfolio Theory: Weaknesses and how to overcome them, In Investments and Wealth monitor, 27-32, Greenwood Village: IMCA

Schulmerich, M., Leporcher, Y. M. \& Eu, C. H. (2015). Modern Portfolio Theory and Its Problems. In Applied Asset and Risk Management, Springer Berlin Heidelberg, 101-173

Singh, T., Mehta, S. \& Varsha, M. S. (2011).Macroeconomic Factors and Stock Returns: Evidence from Taiwan. Journal of Economics and International Finance, 2(4), 210-217, April

Stulz, R. M. (1986). Asset Pricing and Expected Inflation. Journal of Finance, 41, 209-223.

Uanguta, E. \& Ikhide, S. (2002). Monetary Policy Transmission Mechanism in Namibia, Bank of Namibia (BON). Working Paper, No 2/02

Yli-Olli, P., Virtanen I. \& Martikainen, T. (1990). Common Factors in the Arbitrage Pricing Model in Two Scandinavian Countries. OMEGA International Journal of Management Science, 18, 615-624.

Zubair, A. (2013). Causal Relationship between Stock Market Index and Exchange Rate: Evidence from Nigeria. CBN Journal of Applied Statistics, 4(2), 87-110 